\section{0 б myp \\ руш к. . озробк інформ иійно-вимірюв льних предст вленням інформ иії //

\begin{tabular}{|c|c|c|}
\hline$e \beta$ & стьянов & \\
\hline вимірюв & льних & $\kappa н$ лів \\
\hline систем & 3 & совим \\
\hline укові & $\mathrm{OH}$ & \\
\hline
\end{tabular} \\ укові $п$ ц ці он . ип.} 148, 2009. - .188-195.
11. $б$ тур . . ехнологія вимірюв ння $н$ основі предст влення зн чень вимірюв них величин ч совими інтерв л ми : моногр фія / . . б тур .інниця : $\quad 2010 .-324$ c.

дійщл до ред киї 15.10.2010 p.

$$
\text { . . } 6 \text { тур , . . улеко, . . ум кевич }
$$

дним из н иболее перспективных н пр влений р звития бортовых информ ицонных телеметрических систем космических пn р тов является использов ние измерений с предст влением информ иии ч совыми интерв л ми. ст тье предложен в ри нт построения $\quad$ основе предст вления измерений ч совыми интерв $л$ ми.

лючевые слов : бортов я информ ционно-телеметрическ я систем, телеметрический к $л$ связи, р диотелеметрический комплекс, бортовой комплекс упр вления.

\title{
THEORETICAL ASPECTS OF CONSTRUCTION OF TELEMETRIC SYSTEMS OF SPACE VEHICLES WITH SENTINEL PRESENTATION OF MEASURING INFORMATION
}

Yu.V. Shabatura, I.V. Puleko, V.O. Chumakevych

One of the most perspective directions of development of side informatively telemetric systems of space vehicles is the use of measurings with presentation of information by sentinel intervals. In the article the variant of construction of BITS is offered on the basis of presentation of measurings by sentinel intervals.

Keywords: side informatively telemetric system, telemetric communication channel, radiotelemetric complex, side complex of management.

681.3.01:519.67

. ' 'ЯКОВ

к демія ухопутних військ імені гетьм н етр г йд чного, ьвів

озгляд ється проблем комплексного з безпечення достовірності, безперервності $m$ гнучкості з собів ртилерійської розвідки $m$ можливі шляхи ї̈ вирішення, с ме, створення б г тоспектр льних прил дів спостереження $m$ розвідки, що використовують сенсори $n$ рці льних спектр льних $к н$ лів широкому дi $n$ зоні електром гнітних хвиль. озгляд ються інформ ційні спекти комплексув ння спектр льних к н лів.

лючові слов : ртилерійськ інструмент льн розвідк, спектр льний $n$ риі льний $\kappa н \Omega$, 6 г тоспектр льний прил д спостереження, комплексув ння.

\section{ступ}

ост нов к 3 д чі. сновною причиною нез довільного з безпечення достовірними д ними з собів вогневого ур ження є недоскон лі т ктикотехнічні х р ктеристики прил дів ртилерійської розвідки (обмеженість умов ефективного з стосув ння, відсутність можливості д птивної перебудови структури т п р метрів під конкретну з в дову обст новку, що дин мічно змінюється). к пок зують дослідження [1], прил ди, які пр цюють у меж х однієї ділянки спектр електром гнітних хвиль ( ) не з безпечують всієї сукупності з вд нь, які покл дено н розвідув льні підрозділи з необхідною достовірністю в умов $\mathrm{x}$ суч сного високодин мічного бою. б'єдн ння перев г кожного із спектр льних к н лів в р мк х єдиного прил ду спостереження дозволяє вирішити 
сукупність 3 д ч, які ст вляться перед перспективними з соб ми розвідки.

н ліз ост нніх досліджень т публік цій

сьогодні існує досить прогресуюч тенденція до об'єдн ння окремих п рці льних спектр льних сенсорів в р мк х єдиної інформ ційної системи. озвиток отрим ли як теоретичні [2, 3], т к і прикл дні роботи [4]. д ч комплексув ння спектр льних к н лів різних ділянок спектр розгляд ється в робот х [5-7].

ет ст тті. ровести н ліз т визн чити технічні шляхи комплексного з безпечення достовірності, безперервності т гнучкості перс пективних з собів ртилерійської розвідки н основі комплексув ння д них сенсорів різного ді п зону.

\section{снов Н ч стин}

оловною

3 д чею

ртилерійської

інструмент льної розвідки є своєч сне виявлення, розпізн ння і точне визн чення координ т цілей.

ля успішного рішення цієї 3 д чі ртилерійськ розвідк повинн вестися н зн чну глибину (не менш д льності стрільби р кетних і ртилерійських систем), безперервно, ктивно, цілеспрямов но, своєч сно добув ти достовірні т точні д ні [8]. ослідження пок зують, що у суч сних опер ціях більш ніж $85 \%$ розвідув льної інформ ції добув ється технічними з соб ми інструмент льної розвідки.

суч сному високодин мічному бою ртилерійськ розвідк $€$ виріш льною умовою ефективності дій ртилерійських підрозділів і упр вління опер цією ком ндиром 3 г льновійськового з'єдн ння. ме висок дин мік суч сного бою вим г є від з собів розвідки швидкої д пт ції їх структури т п р метрів під конкретну з в доцільову обст новку для досягнення н йвищої ефективності з стосув ння.

е ліз ція нових концепцій ведення бойових дій, що з снов ні н з стосув нні високоточних 3 собів ур ження, інтенсивний технічний прогрес в обл сті р діоелектронних т інформ ційних технологій привели до появи якісно нових комплексів індивіду льного з хисту, що суттєво знижують помітність озброєння т військової техніки ( ) пр ктично у всіх ді п зон х , широкого використ ння 3 ходів комплексної протидії - м невр цілі, пост новк 3 в д, вогнев протидія т інше. м г ння з безпечити ефективне функціонув ння системи упр вління і 3 умови протидії противник обумовлює підвищення з в доз хищеності при збереженні достовірності, безперервності т гнучкості розвідки.

з г льному вип дку комплексну 3 д чу розвідки т упр вління вогнем і можн декомпозиціюв ти. івнями т озн к ми декомпозиції є: т ктичні вимоги, технічні шляхи ре ліз ції т ктичних вимог, режими (ет пи) інструмент льної розвідки, з д чі упр вління (рис. 1).

остовірність розвідки можн визн чити як основну х р ктеристику, як може бути, з однієї сторони, покл ден в якості критерію при оптиміз ції прил ду інструмент льної розвідки, 3 іншої сторони допуск є строгий кількісний опис в p мк х інформ ційного підходу 3 допомогою кількості інформ ції про ціль, що отримується (інформ тивність), нез лежно від фізичної природи сенсорів розвідув льної інформ ції. кщо в якості критерію бойової ефективності при синтезі оптим льного прил ду розвідки прийняти м ксим льну достовірність, то безперервність, що досяг ється можливістю ведення розвідки у будьякий ч с доби т з будь-яких погодних умов, i гнучкість, шо досяг ється можливістю д пт ції структури і п р метрів п р тури до фоноцільової обст новки, можуть бути віднесені до експлу т ційних обмежень $[9,10]$.

рівні режимів (ет пів) роботи прил дом ртилерійської розвідки, в з г льному вип дку, вирішуються три основні з вд ння:

- пошук т виявлення цілі, що поділяється н низку підз д ч: селекція цілі н фоні орг нізов них т природних 3 в д, виявлення цілі т цілевк зув ння вогневим з соб м;

- оцінк (вимірюв ння) координ т, що включ $\epsilon$ прицілюв ння т н ведення (с мон ведення) озброєння;

- розпізн ння цілі з безпечує процеси вибору прицільної точки т визн чення пріоритетності обстрілу фр гментів сцени, що спостеріг ється.

інцевим т ктичним рівнем комплексної з д чі упр вління вогнем ртилерійських підрозділів є вибір вогневого 3 собу з результ т ми пошуку т виявлення цілі, з безпечення точності вогневого ур ження 3 результ т ми вимірюв ння координ т цілей, т кож вибір боєприп су 3 результ т ми розпізн ння цілі.

к відмічено вище, прил ди ртилерійської розвідки, які пр цюють у меж х однієї ділянки спектр , не з безпечують всієї сукупності 3 вд нь 3 необхідною достовірністю в умов х суч сного бою.

к, оптичний (довжин робочої хвилі $\lambda \approx$ $0,5$ мкм $)$ т інфр червоний $(\lambda \approx 2 \ldots 14$ мкм $)$ к н ли спостереження м ють високу кутову роздільну зд тність, оскільки $\frac{\ell_{0}}{\lambda} \geq 1\left(\approx 10^{5}-10^{6}\right)$, де $\ell_{0}-$ лінійний розмір пертури прил ду, дозволяють формув ти зобр ження об'єкт (сцени), що спостеріг ється, у "к ртинній" площині т добре узгоджуються 3 психофізіологічними 

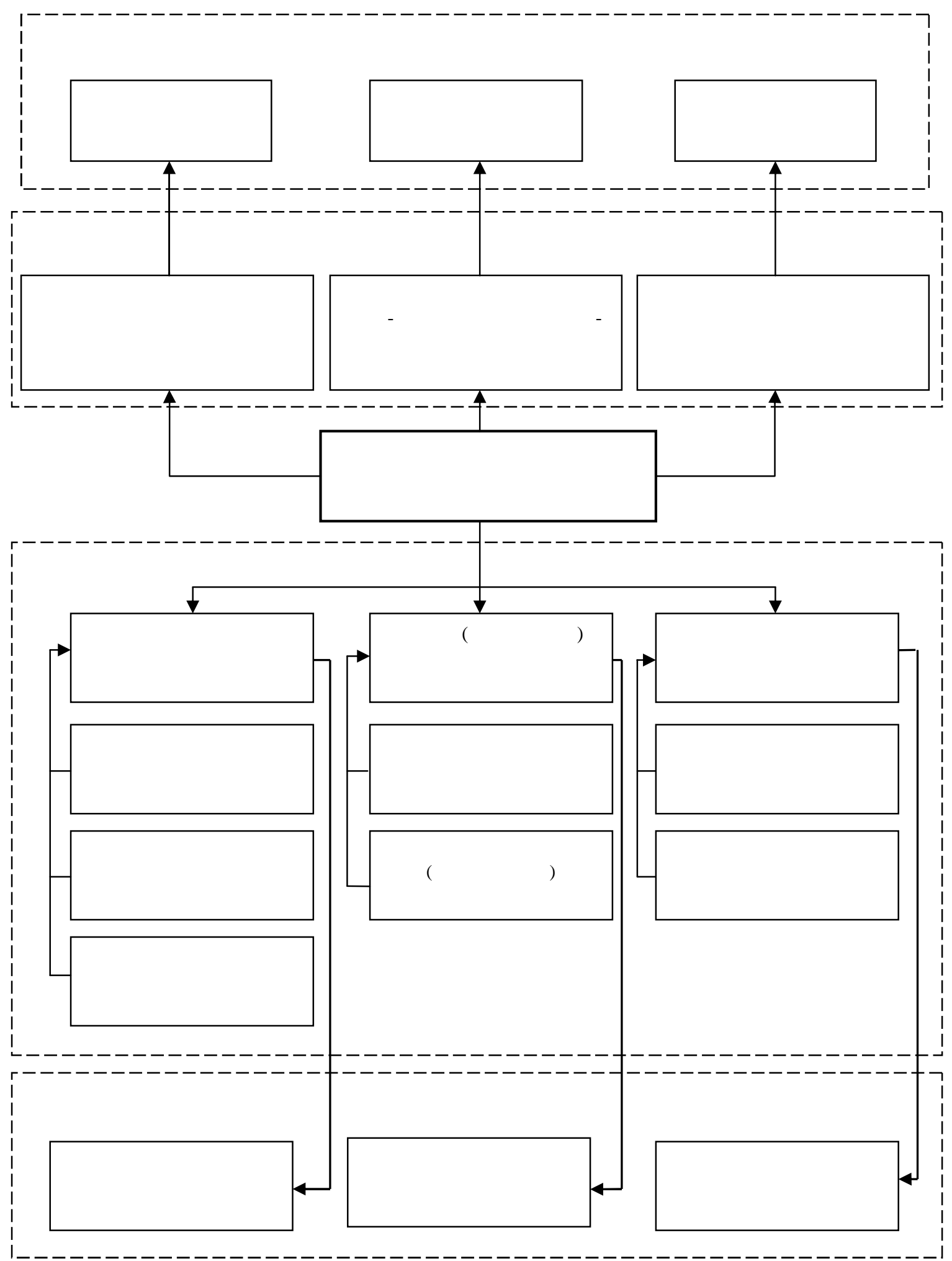

uc. 1. екомпозиція комплексної з д чі розвідки т упр вління вогнем і

особливостями опер тор - гомою перев гою оптичного т інфр червоного ( ) к н лу $є$ його особливість вести прихов не (без випромінюв ння) спостереження. зом $з$ цим д ним К н л м прит м нний ряд суттєвих недоліків:

- $з$ лежність х р ктеристик, в першу чергу д льність дії, від прозорості приземного ш ру тмосфери (гідрометеори, дим, пил, ерозолі); 
- м ле миттєве кутове поле зору, що при пріорній невизн ченості просторового положення цілі суттєво збільшує ч с н ії пошук т виявлення;

$$
\text { - різке п діння інформ тивності зі }
$$
збільшенням відст ні до цілі вн слідок зрост ння лінійного елементу роздільної зд тності.

к, швидкість п діння кількості інформ ції про цілі в оптичному ( ) може бути визн чен як [10]

$$
\frac{d I_{\text {onm }}^{*}}{d D}=-\frac{2 L_{\beta} L_{\varepsilon}}{\gamma \cdot \operatorname{tg}^{2} \Delta Q D^{3}}
$$

той ч с як для р діолок ційного к н лу

$$
\frac{d I_{p \Omega}^{*}}{d D}=-\frac{2 L_{D}}{\Delta D \ln 2 D}
$$

де $L_{6}, L_{\varepsilon}, L_{D}$ - лінійні розміри цілі по зимуту, куту місця, д льності; $\Delta Q-$ кутов роздільн зд тність; $\Delta D$ - роздільн зд тність по д льності; $\quad \gamma \geq 1$ коефіцієнт оптичної прозорості тмосфери, який визн ч ється як відношення д льності оптичної видимості при ст нд ртних п р метр х тмосфери до д льності 3 н явності 3 в д (дощ, тум Н, сніг, дим т ін.)

діоді п зон $(\lambda \geq 2 \mathrm{Mм})$ з безпечує викон ння з д ч цілодобово т 3 будь-яких погодних умов, н д $є$ можливість отрим ння інформ ції про д льність цілі т ії допплерівські х р ктеристики, м є широке миттєве поле зору. о недоліків відноситься фкт відсутності високої кутової роздільної зд тності $\frac{\ell}{\lambda}>1\left(\approx 10^{2}\right)$, де $\ell$ - лінійні розміри нтени. слідком цієї обст вини є використ ння у пр ктиці побудови р діолок ційних прил дів ртилерійської розвідки мікрохвильового ді п зону т зокрем міліметрового ді п зону ( ). ншим недоліком $€$ зниження однієї 3 х $\mathrm{p}$ ктеристик ведення розвідки - прихов ності,

т кож схильність до впливу орг нізов них 3 в д. ожН ВИзН чИти умови бойового 3 стосув ння для прил дів, що 3 стосовують різні ділянки

- оптичні з соби - ясн погод (відсутність оп дів), день;

- тепловізійні з соби ді п зону - можуть ефективно пр цюв ти вдень і вночі, 3 відсутності оп дів, пилу, диму, м скув льних ерозолів;

- p діолок ційні з соби - ефективно 3 стосовуються вдень і вночі, 3 будь-яких метеоумов, н явності димових т ерозольних 3 в д. ким чином, об'єдн ння перев Г сенсорів кожної з ділянок спектр дозволяє вирішити сукупність 3 д ч, які ст вляться перед перспективними з соб ми ртилерійської інструмент льної розвідки. н кше, в більш широкому сенсі, мов йде про розширення інформ ційної смуги б г тоспектр льного прил ду спостереження, формув ння якої ілюструє рис. 2.
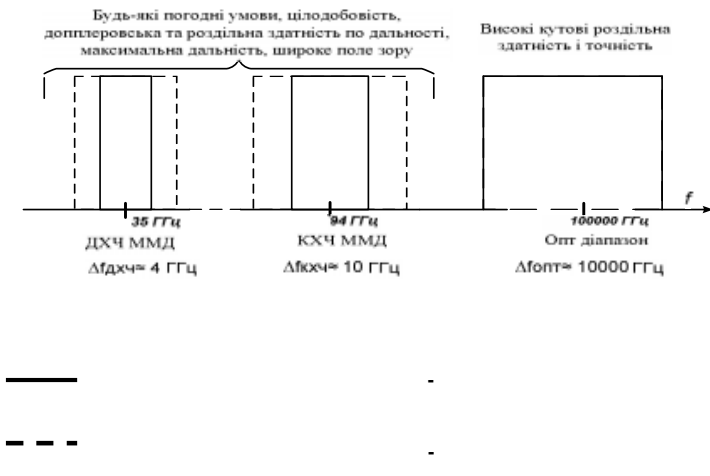

ді п зону

uc. 2. ормув ння інформ ційної смуги

б г тоспектр льного прил ду спостереження

ід комплексув нням к н лів будемо розуміти сукупність технічних рішень н п р тному i прогр мному рівнях, спрямов них н підвищення ефективності 3 собів спостереження 3 р хунок об'єдн ння експлу т ційних і інформ ційних перев г к н лів спостереження різних ділянок спектр . і п зон змін відносного пок зник ефективності н віть для двоспектр льної системи може колив тися від 0 (приросту ефективності нем є) до 1 (для вип дку, коли один 3 к н лів цілком не пр цює, н прикл д, через ур ження перешкодою).

з г льному вип дку комплексув ння може прийм ти дві форми:

- інформ ційне комплексув ння. ередб ч $є$ п р тно-прогр мне об'єдн ння к н лів 3 метою досягнення інформ ційних перев г б г тоспектр льної системи н всіх ет п х спостереження (виявлення, вимірюв ння координ т і п р метрів руху, розпізн в ння об'єктів, що спостеріг ються);

- конструктивне комплексув ння (інтегр ція). ередб ч є об'єдн ння к н лів різних ді п зонів у p мк х єдиного п р турного викон ння 3 метою зменшення в гог б ритних х р ктеристик i поліпшення експлу т ційних пок зників (вз ємосинхроніз ції і вз ємоюстув ння к н лів) [10].

нформ ційне комплексув ння, у 3 г льному вип дку, допуск є об'єдн ння перев г спектр льних К н лів н рівнях:

- просторових вибірок формов них зобр жень об'єктів, що спостеріг ються, і сцен (піксельний рівень);

інформ тивних озн к об'єктів, що спостеріг ються, і сцен;

- ст тистичних рішень, що прийнято ПОК Н ЛЬНО. 
іксельний рівень дозволяє комплексув ти к н ли з порівняльними просторовими роздільними зд тностями. кими к н л ми можуть бути суміжні ділянки видимого спектр , інфр червоного ( ) ді п зону, . н чне рознесення по ді п зону к н лів, що комплексуються (н прикл д, т p діоді п зон), н цьому рівні неможливо через пр ктичні обмеження, пов'яз ні із допустимими розмір ми і точністю виготовлення нтенних систем к н лів р діоді п зону, шо не дозволяе досягнути порівняних кутових роздільних зд тностей п рці льних к н лів.

омплексув ння н рівні інформ тивних озн к м є дві особливості:

- комплексув ння н рівні інформ тивних озн к, отрим них у єдиній системі координ т, т кож як і в попередньому вип дку, вим г є співмірності роздільних зд тностей спектр льних к н лів;

- при комплексув нні к н лів з істотно різними роздільними зд тностями 3 сукупністю п р метрів прийнятих сигн лів, підвищення ефективності б г тоспектр льної системи досяг ється 3 р хунок збільшення розмірності сформов них зобр жень.

к, н прикл д, н явність роздільної зд тності ктивних к н лів р діоді п зону 3 д льністю і допплерівським зсувом ч стоти дозволяє доповнити оптичні зобр ження в к ртинній площині, одержув ні з р хунок високої кутової роздільності, д льнісними і допплерівськими "портрет ми" [11]. цьому вип дку для інформ ційної оцінки б г тоспектр льного прил ду спостереження т розвідки доцільно з стосув ти методологію оцінки, що прийнят в б г тоспектр льних відеоспектрометр х для дист нційного геомоніторінгу [12]. ри цьому інформ ційний опис б г тоспектр льного прил ду предст вляється гіперспектр льним "кубом" інформ ції, дв виміру якого відповід ють просторовому зобр женню сцени, що спостеріг ється в "к ртинній" площині (з лежність яскр вістного т теплового контр сту цілі від кутових координ т), третє - центр льній ч стоті п рці льного спектр льного к н лу. відміну від відеоспектрометр в б г тоспектр льному прил ді ртилерійської розвідки інформ ційний "куб" деформується н ступним чином:

- кількість п рці льних к н лів зменшується 3 кількох сотень до трьох (оптичний, т р діолок ційний);

- в п рці льному к н лі р діоді п зону зобр ження цілі переформ тується 3 системи координ т " зимут-кут місця" в систему координ т "д льність-допплерівськ ч стот " (з лежність p діолок ційного контр сту). лід відмітити, що методологія розр хунку інформ ції, що отримується для $б$ г тоспектр льного прил ду спостереження і розвідки н логічн відеоспектрометру - 3 допо- могою просторових елементів роздільної зд тності: зимут льних і кутомірних (для оптичного т к н лів) i д льнісних т допплерівських (для p діок н лу) відповідно $[10,12]$.

омплексув ння н рівні ст тистичних рішень, прийнятих пок н льно $€$ н йбільш 3 г льним підходом до підвищення ефективності б г тоспектр льних систем. ри цьому фізичні принципи побудови к н лів ( ктивний, н пів ктивний, п сивний), що комплексуються т ступінь н ближення їхньої структури до оптим льного не м є зн чення. точки зору теорії ст тистичних рішень у досить 3 г льній пост новці проблем спостереження, нез лежно від ділянки спектр

, що з йм е спектр льний п рці льний к н л, може бути поділен н три 3 д чі: виявлення цілі, вимірюв ння (оцінк ) координ т цілі, розпізн ння (б г то льтерн тивне виявлення) цілі.

етодом м ксимуму пр вдоподібності в робот $\mathrm{x}[13,14]$ отрим но оптим льні лгоритми рішення вищевк 3 них окремих 3 д ч 3 г льної проблеми спостереження в 6 г тоспектр льних прил д х спостереження.

дноч сно пок з но, що в з г льному вип дку ефективність б г тоспектр льного прил ду спостереження, нез лежно від рівня комплексув ння п рці льних спектр льних к н лів, збільшується зі збільшенням ї кількості т м ксим льного рознесення по ч стоті. зом з цим ясно, що з умов високої дин мічності з в дової обст новки повинн проводитися оцінк з в дової ситу ції т здійснюв тися д птивн перебудов п рці льних спектр льних к н лів. ідповідн методологія розроблен в роботі [15] т грунтується т кож н 3 стосув нні методу м ксимуму пр вдоподібності.

ля $з$ безпечення вз ємоузгодженої роботи п рці льних спектр льних к н лів у просторі т ч сі в робот $\mathrm{x}[16,17]$ розроблен методологія т технічні в рі нти конструктивного комплексув ння (інтегр ції). езпосередніми фізичними передумов ми для створення інтегров них б г тоспектр льних прил дів ртилерійської розвідки є:

- можливість об'єдн ння п рці льних спектр льних к н лів у р мк х єдиної електродин мічної просторово-ч сової схеми ді гр моутворення;

$$
\text { - інв рі нтність структури п р тно- }
$$
прогр мної ч стини б г тоспектр льної системи до типу фізичного сенсору п рці льного спектр льного к н лу після н лого-цифрового перетворення к н льної інформ ції;

- можливість використ ння для візу ліз ції інформ ції з виходу б г тоспектр льного прил ду спостереження єдиних індик торів. 


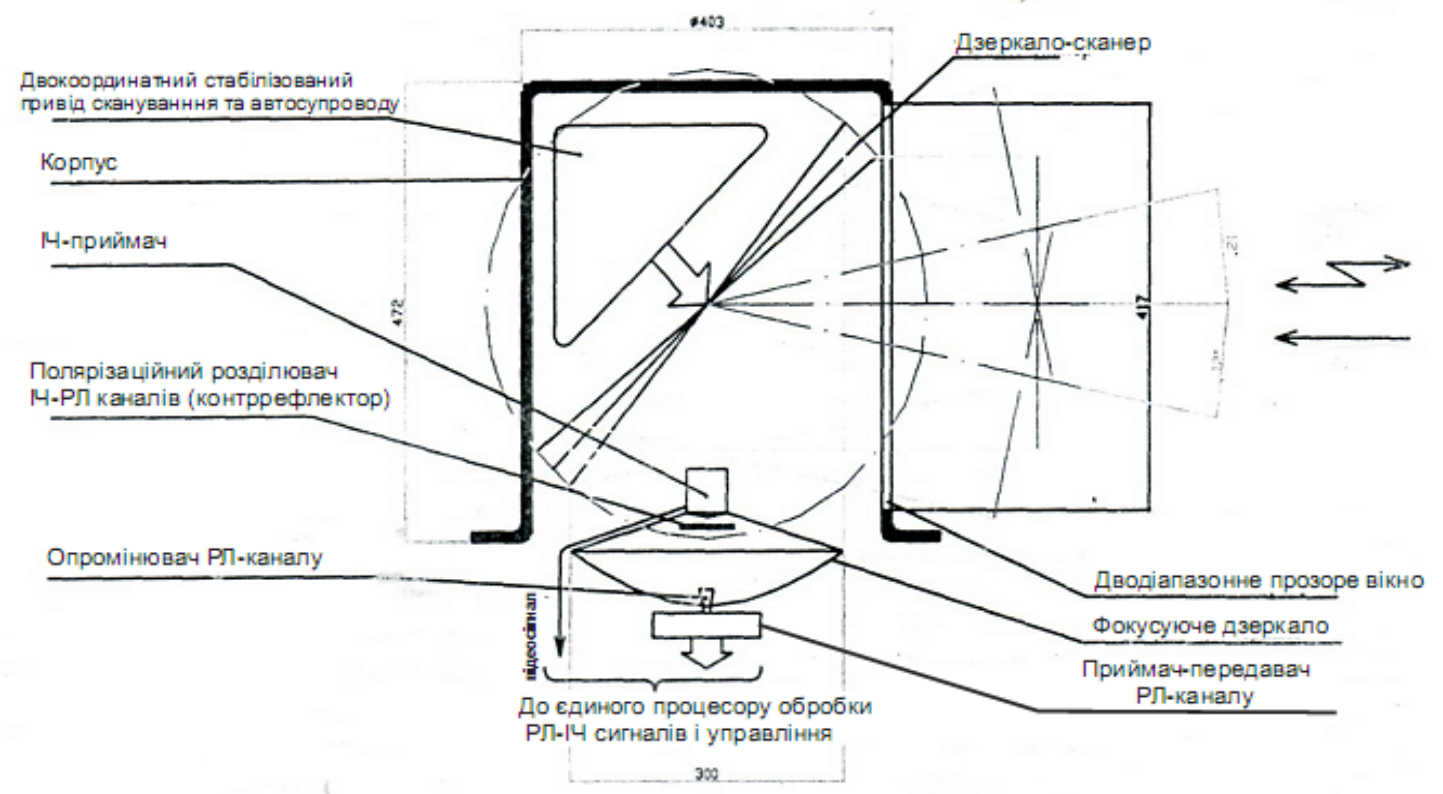

uc. 3. pi нт конструкції інтегров ного р діооптичного блок

ри цьому, н відміну від 6 г тоспектр льних систем з різними пертур ми сенсорів п рці льних спектр льних к н лів (н прикл д, д тчик цілі боєприп су "Smart" [18]) може бути досягнуто суттєвого ефекту у в гог б ритних т експлу т ційних х $р$ ктеристик х.

pi нт конструкції інтегров ного p діооптичного пошуково-прицільного прил ду для розміщення н рухомому розвідув льному пункті предст влено рис. 3 .

$$
\text { е ліз ція оптим льної }
$$

інтегров ного 6 г тоспектр льного

структури спостереження виключ $€$ необхідність пріорної інформ ції про з в доцільову обст новку як у вип дку опер тор , т к і в втом тизов ній системі упр вління р кетно- ртилерійським озброєнням.

ким чином, можн стверджув ти, що с ме комплексув ння ктивно-п сивних к н лів спостереження різних ділянок спектр у р мк х єдиної інформ ційно-вимірюв льної системи, тобто створення б г тоспектр льного прил ду розвідки т спостереження $є$ потужним з собом підвищення бойової ефективності перспективних з собів ртилерійської розвідки. пропонов ні технічні шляхи вдоскон лення прил дів інструмент льної ртилерійської розвідки для досягнення необхідних т ктичних х р ктеристик інв рі нтні до кінцевого об'єкт користув ч інформ цією прил ду розвідки (людин -опер тор бо втом т) уст ткув ння прил ду (рухомий розвідув льний пункт, вогневий з сіб бо координ тор цілі бойового елемент ).

\section{иснов К И}

1. ніверс льним методом рішення проблеми комплексного з безпечення достовірності, безперервності т гнучкості з собів ртилерійської розвідки є створення б г тоспектр льних прил дів спостереження т упр вління озброєнням 3 фізичними сенсор ми цілей різних ділянок спектр електром гнітних хвиль. ри цьому:

- підвищення достовірності досяг ється 3 p хунок розширення інформ ційної смуги т можливості компіляції зобр жень, що формуються у фотоконтр стних, теплоконтр стних т p діолок ційних п рці льних спектр льних к н л х 6 г тоспектр льного прил ду;

- безперервність: вимоги до з стосув ння у будь-який ч с доби т 3 будь-яких погодних умов з безпечуються мініміз цією ймовірності придушення з в дою одноч сно всіх п рці льних спектр льних к н лів б г тоспектр льного прил ду;

- гнучкість з безпечується д пт цією під пріорі невідому т дин мічну з в доцільову обст новку шляхом р нжув ння величин модулей перед тних функцій п рці льних спектр льних к н лів 3 результ т ми н лізуз в дової обст новки.

2. р ктичній ре ліз ції 6 г тоспектр льних прил дів ртилерійської розвідки супутні серйозні конструктивно-експлу т ційні обмеження, пов'яз ні 3 мініміз цією п р тно-прогр мних об'ємів, в ги т енергоживлення п р тури, які можуть бути подол но шляхом об'єдн ння к н лів різних ді п зонів у $\mathrm{p}$ мк х єдиного п р турного викон ння 3 метою зменшення в гог б ритних х р ктеристик $\mathrm{i}$ поліпшення експлу т ційних пок зників. 


\section{писок літер тури}

1. ренев .. симметричный ответ высокоточному оружию: [ лектрон. ресурс]. - ежим docmyny: http://www.sinor.ru/ bukren11/asimm_otvet1.htm.

2. лексеев . . иенк кчеств функциониров ния интегр льной оптико-р диолок ционной головки с мон ведения / . . лексеев, . . нкг льтер . . урилкин, . . оченов // диотехник . - 2004. №11. - . .3-11.

3. лексеев . . еоретическ я модель системы селекции комбиниров нной оптико-р диолок ционной головки с мон ведения / . . лексеев, . . нкг льтер, . . урилкин, . . оченов // диотехник . - 2003. №10. - . .5-13.

4. $р$ сов . ., кушенков .. ногоспектр льные оптико-электронные системы [ лектрон. ресурс]. - ежсим доступy: http://www.cyclone-jsc.ru

5. убков . . нтегриров нные многоспектр льные системы геомониторинг . ониепция построения. .1. ежждун родн я конференция "овременные $и$ преспективные системы р диолок иии, $p$ дио строномии и спутниковой н виг иии» $($-2008). . 1/. . убков, . рудиус // б. н учных трудов 3-го ежлдун родного $\quad$ диоэлектронного форум «рикл дня р диоэлектроник. остояние и перспективы р звития»('2008).

6. убков . . нтегриров нный двухспектр льный всепогодный $и$ всесуточный поисково-прицельный комплекс /. . убков, . . в нов, . . 3 ков// борник трудов 4 еждун родной конференции " ртиллерийские ствольные системы, боеприп сы, средств ртиллерийской р зведки и упр вления огнем". . - 2000. - .200-203.

7. олосюк. омплексиров ние ктивных и $n$ ссивных р диолок иионных систем дист нционного зондиров ния / . . олосюк, . . р вченко // рубежн я р диоэлектроник . -2002. - №2. - .3-23.

8. ривошеєв. ., риходько .., етренко. ртилерійськ розвідк : вч льний посібник. - уми: yм , 2009. - $277 c$.

9. усленко . ., л шников .., ов ленко . екции по теории сложных систем. - .. " оветское р дио", 1973. - 440 c.
10. убков . . ногоспектр льные приборы поиск, прицелив ния и н ведения р кетно- ртиллерийского вооружения. остижения и перспективы р звития / . .убков, . . рудиус, . . вяков и др. // ерспективи розвитку озброєння $m$ військової техніки ухопутних військ: бірк тез доповідей ругой сеукр їнської н уково-технічної конференції 28-29 квітня 2009р. - ввів, 2009. - . 8-15.

$$
\text { 11. т. } 91299 \text { кр їн, G01S 13/00, G01J 3/28. }
$$

посіб визн чення геометричних $x$ р ктеристик $i$ $n$ р метрів руху н земних об'єктів при геомоніторингу $i$ систем для його ре ліз ції / . . убков, I. . рудіус, . . зько, . . имріков ( кр їн ). - №200904541; явлено 07.05.2009. - публ. 12.07.2010. - юл. №13.

12. A. Dyakov. Information approach to estimation of the multispectrum monitoring device efficiency // TCSET'2010, Febriary 23-27, 2010. - P.86.

13. убков . . нтегр иия $п$ рии льных спектр льных $\kappa$ н лов координ тор, $\kappa \kappa$ способ повышения точности $u$ помехоз щищенности / . . убков, . . ртыненко // истеми упр вління, н віг ції $m$ зв'язку. - 2008. - ип. 4 (8). - .32-33.

14. Зубков А.Н. Интегрированные многоспектральные поисково-прицельные системы для ракетно-артиллерийского вооружения / А.Н. Зубков, А.А. Щерба // Артиллерийское и стрелковое вооружение. - 2009. - №1. - С. 14-18.

15. убков . н ніз тор з в дової обст новки для д птивної б г тоспектр льної системи спостереження / . . убков, . . 'яков, . . ртиненко, . . ерб // існик інницького політехнічного інституту. - 2010. - №4(91). - . 68-70

16. тент 70868 кр їн, G01J11/00, G01S13/00. посіб дист нційного моніторингу земної поверхні $m$ інтегров н систем для його ре ліз ції / . . убков, I. . рудіус, . . меркло ( $к р$ їн ). №20031213144; явлено 30.12.2003. - публ. 15.10.2004. - юл. №10.

17. Frank Vizard. Smart Artillery // Popular Science. 1998. - March. - . 27

дійшл до редк кцї̈ 18.10.2010р.

ецензент: доктор технічних н ук, ст рший н уковий співробітник . . убков, к демія сухопутних військ імені гетьм н етр г йд чного, ьвів.

. . ьяКов

ссм трив ется проблем комплексного обеспечения достоверности, непрерывности и гибкости средств ртиллерийской р зведки и возможные пути её решения, именно, созд ние многоспектр льных приборов н блюдения и р зведки, которые используют сенсоры $n$ рци льных спектр льных к н лов в широком ди $n$ зоне электром гнитных волн. ссм трив ются информ ционные спекты комплексиров ния спектр льных к н лов.

лючевые слов : ртиллерийск я инструмент льн я р зведк, спектр льный $п$ рци льный к н л, многоспектр льный прибор н блюдения, комплексиров ние.

\section{THE PROBLEM OF INTEGRATED SOFTWARE RELIABILITY, CONTINUITY AND FLEXIBILITY OF ARTILLERY RECONNAISSANCE AND TECHNICAL WAYS TO SOLVE IT}

\section{A.V. Dyakov}

The problem of complex software reliability, continuity and flexibility of artillery reconnaissance and possible ways of its solution, namely, the creation of multi-spectral surveillance and reconnaissance devices that use sensors partial spectral channels in a wide range of electromagnetic waves is considered. Information aspects of complexation spectral channels are examined.

Keywords: rtillery instrumental reconnaissance, spectral partial channel, multispectral surveillance device, complexing. 